On the 6th of March, Executive Director Spengler was in Washington, D.C., for the Annual Science ServiceWestinghouse Banquet and presentation of the Westinghouse Science Talent Scholarships. The following day he was in Philadelphia where he was joined by Director of Publications, James Caskey, for meetings of the National Federation of Abstracting and Indexing Services. Mr. Spengler attended the 20th anniversary dinner of the federation as a Past President; he returned to Boston on the 8 th.

On the 9th, the Admissions Committee met at Headquarters; committee members Keegan, Pierce, J. Spengler, and Sherr were in attendance.

On the 13th, Mr. Spengler and his assistant, Evelyn Mazur, traveled to Atlantic City for the Fifth Conference on Fire and Forest Meteorology. They returned to Boston on the 16th.

On the 21st, Mr. Spengler attended the Greater Boston AMS Chapter meeting.

The Executive Committee met on the 23rd and 24th at Headquarters; attending were: President Cressman, President Elect Newton, Past President Baum, Councilors Leep, Ackerman, and Wallace, Executive Director Spengler, and Secretary-Treasurer Landrigan.

On the $27 \mathrm{th}, \mathrm{Mr}$. Spengler attended the mid-year meeting of the Council of Engineering and Scientific Society Executives in Washington. The meeting was on public policy and included a briefing by the President's Science Advisor, Dr. Frank Press, and his OSTP staff. That evening Mr. Spengler traveled to Atlanta for the 18th Conference on Radar Meteorology. Meetings Editor Evelyn Mazur and Assistant Meetings Editor Kathleen Forrest were in Atlanta all week coordinating the meeting.

On the 30th, Mr. Spengler returned to Boston to host a meeting, held on the 31st, of the international Steering Committee for the Colloquium on the Role of Science and Technology in the Development Process. Attending were: Dr. Maurice Goldsmith (convenor), Science Policy Foundation, London; Dr. Thomas F. Malone (chairman), Holcomb Research Institute, Indianapolis; Dr. Louis Berlinguet, International Development Research Center, Ontario; Dr. H. O. Halvorson, Brandeis University, Waltham, Mass.; Prof. Larkin Kerwin, Laval University, Quebec; Dr. A. Keynan, Hebrew University of Jerusalem; Dr. Alexander King, International Federation of Institutes for Advanced Study, Stockholm; Dr. Ward Morehouse, Council of International and Public Affairs, New York; Prof. S. Ramakrishna, Raman Research Institute, India; Dr. Roger Revelle, University of California, San Diego; Sir Hugh Springer, Association of Commonwealth Universities, London; Dr. H. Guyford Stever, Washington, D.C.; Dr. Charles S. Dennison, Council on Science and Technology for Development, Washington, D.C.; F. W. G. Baker, ICSU, Paris; and Mrs. M. M. Treichel, NAS, Washington, D.C.

Visitors to Headquarters during the month included: Keith Synnestvedt, Pa.; A. Cort, Boston; David F. McGinnis, Jr., Washington, D.C.; Lori Kaloesdian, Carol Obertubberg, and Kirit Mookerjee, Medford, Mass.; Karen Lacey, Bozeman, Mont.; Mr. and Mrs. Jerome M. Clemens, Dayton, Ohio; Richard K. Davis, Philadelphia; R. P. Snyder, Decatur, Ill.; Vincent J. Schaefer, Schenectady; Richard L. Reino, Bridgewater, Mass.; Evan Johnston, Amherst, Mass.; Bonnie Tuttle, Mich.; Dennis and Jean Darling, Kalamazoo; and Pauline Barber, Frankfort, Mich.

\title{
Report of the 1978 Nominating Committee
}

The 1978 Nominating Committee of the American Meteorological Society, consisting of Louis J. Battan, Chairman, Neil L. Frank, Peter R. Leavitt, Alfred C. Molla, Jr., and Warren M. Washington, submits the following list of nominees for President-Elect and Councilor to be elected by mail ballot prior to the next Annual Meeting in January 1979.

for President-Elect, 1979

Paul W. Kadlec

Robert M. White

\author{
for Councilor, 1979-80-81 \\ Eugene W. Bierly \\ Elbert W. Friday, Jr. \\ Tiruvalam N. Krishnamurti \\ Stanley L. Rosenthal \\ Douglas H. Sargeant \\ Harlan K. Saylor \\ Joanne Simpson \\ Conley R. Ward
}

In accordance with the constitutional amendments adopted in January 1966, the person who is elected to be President Elect in 1979 will serve as President in 1980.

It is provided in Article $\mathrm{V}$ of the By-Laws of the Society that nominations also may be made by petition signed by at least 50 members eligible to vote on the preceding May 1 , provided the petition is received by the Secretary-Treasurer, together with the written consent of the nominee, not later than the next following September 1.

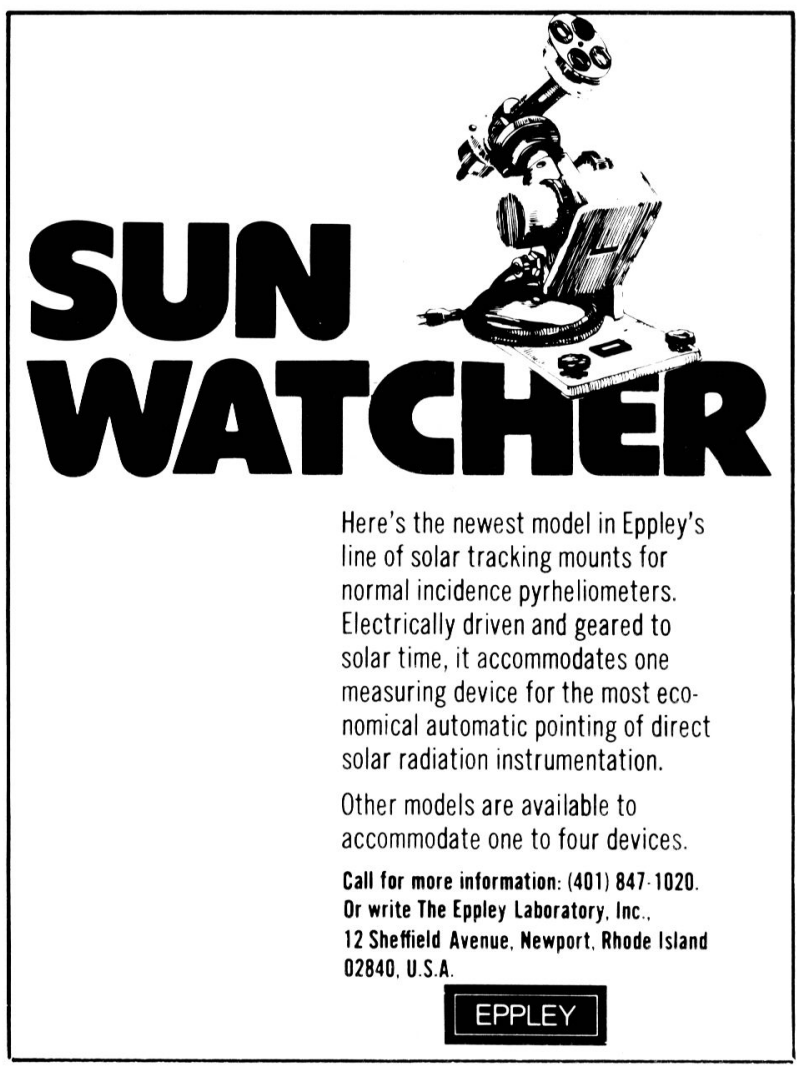

